\title{
ResearchArticle
}

\section{Occurrence of Alternaria brassicae in seed-producing cauliflower and its role of seed infection}

\author{
Mohammad Ansar and Abhijeet Ghatak
}

\section{SUMMARY}

The dark spot pathogen of cauliflower, Alternaria brassicae, is a common problem in east and north-east Bihar. Occurrence of this disease is repeatedly observed in crucifers of this region. The disease is more severe in those areas where seed production of crucifers is practiced. Therefore, we designed this experiment including the natural occurrence of dark spot disease and the survivability of the pathogen in the seed. In our location, the disease is started to appear in January. However, the peak period of this disease on foliage was middle February to middle March. This experiment also envisaged that $A$. brassicae can actively survive for a period of two months on the seed of cauliflower. The seeds obtained from late matured pods had significantly higher seed infection $(P<0.05)$ compared to seeds from early mature pods. This paper renders the evidence for development of new initiative to manage this disease such as development of physical or chemical seed treatment method that sustains effectively for two months and development of variety with early and synchronous podding, and other programmes may be encouraged. Management strategies of this pathosystem are briefly discussed.

Key Words : Alternaria brassicae, Cauliflower, Dark spot, Seed infection

How to cite this article : Ansar, Mohammad and Ghatak, Abhijeet (2018). Occurrence of Alternaria brassicae in seedproducing cauliflower and its role of seed infection. Internat. J. Plant Sci., 13 (1): 67-70, DOI: 10.15740/HAS/IJPS/13.1/67-70.

Article chronicle : Received : 14.07.2017; Revised : 17.11.2017; Accepted : 01.12.2017 